\title{
Marcin Piglowski*
}

Gdynia Maritime University

\section{NOTIFICATIONS TO FOOD FROM EUROPEAN UNION COUNTRIES IN THE RASFF}

\begin{abstract}
In the article there is presented a study which investigated from which European Union countries dangerous food under the Rapid Alert System for Food and Feed (RASFF) was most commonly notified. 13,662 notifications from 2000 to 2015 were examined. The cluster analysis using tree clustering and k-means clustering was applied, as well as scatterplots. The programs Excel and Statistica 12 were used for the necessary calculations. The relationship between the origin country of dangerous food and other variables (and values that occurred most often) were indicated: product category (fish from Spain, meat from Germany), product type (food), notification type (alert and information), year (2011-2014), notification basis (official controls on the market), notifying country (according to product categories: Italy, Germany), distribution status (distribution on the market (possible)), actions taken (withdrawal from the market, recall from consumers) and risk decision (undecided).
\end{abstract}

Keywords: dangerous food, European market, Rapid Alert System for Food and Feed (RASFF)

JEL codes: C38, F40, L66, N34, N74

* E-mail address: m.piglowski@wpit.am.gdynia.pl. 


\section{Introduction}

The framework regulation for food law is regulation (EC) No 178/2002 of the European Parliament and of the Council, laying down the general principles and requirements of food law, establishing the European Food Safety Authority and laying down procedures in matters of food safety. It defines food terminology, prohibits the placing on the market of dangerous and falsified food, imposes the responsibility for food safety on producers, imposes the obligation to traceability, obliges to withdraw from the market food that does not meet safety requirements, introduces the obligation to apply food law to products imported and exported from the European Union (EU) and establishes the Rapid Alert System for Food and Feed. In terms of the general issues of hygiene in food production and trade, the most important are the regulations: No 852/2004 of the European Parliament and of the Council on the hygiene of foodstuffs, No 853/2004 of the European Parliament and of the Council laying down specific hygiene rules for food of animal origin and No 854/2004 of the European Parliament and of the Council laying down specific rules for the organisation of official controls on products of animal origin intended for human consumption (Śmiechowska, 2013, p. 16, 17).

The RASFF (acting on the basis of the mentioned regulation No 178/2002) is a tool used by food (and feed) control authorities to exchange information about risk detected in relation to food (and feed) (European..., 2016, p. 6). In turn, the RAPEX (Rapid Alert System for non-food dangerous products) was established under the directive 2001/95/EC of the European Parliament and of the Council on general product safety. However, specific systems are also in place for medical devices and pharmaceuticals (European..., 2013, p. 10, 53).

These information within the RASFF are exchanged between its members, i.e.: EU countries and also Switzerland, Norway, Iceland, Lichtenstein, the European Commission, European Food Safety Authority and European Free Trade Association Surveillance Authority. An alert notification is sent when food (or feed) presenting a serious risk is on the market and rapid action was or may be required. An information notification concerns food (or feed) for which a risk was not serious or the product was not on the market. A border rejection is sent when consignment of food (or feed) was refused entry into the EU for reason of a risk for human health (European..., 2016, p. 6, 7). 
In the annual RASFF report for 2015 Europe was second world region (after Asia) with the highest number of notifications in the period 2000-2015 (European..., 2016, p. 36). Therefore, the goal of the study was to examine from which EU countries food was most frequently notified, taking into consideration: product category, product type, notification type, year, notification basis, notifying country, distribution status, action taken and risk decision.

\section{Data and methods}

In the RASFF database, the following search criteria were adopted: date - between 01.01.2000 and 31.12.2015, flagged as - origin and country, each out of the $28 \mathrm{EU}$ countries. After searching, the data were ordered in Excel. The obtained data $(13,662$ notifications) concerned ten variables: origin country, product category, product type, notification type, year, notification basis, notifying country, distribution status, action taken and risk decision.

In case of variable notification type the values: information, information for attention and information for follow-up were changed to one value information notification. In case of variables: notification basis, action taken and distribution status, some values were empty, therefore they were filled with the phrase "(not specified)". The data related to feed products and obsolete products were removed.

Then the data were transferred to Statistica 12. For the cluster analysis, the following settings were adopted: joining (tree clustering), linkage rule, complete linkage and distance measure, Euclidean distance. There was also k-means clustering with indicating two, three, four or five clusters used. The relationships between variable origin country and other nine variables were presented in (bubble) scatterplots.

\section{Results and discussion}

In figure 1, the results of tree clustering were presented. There were two clusters formed. The first cluster consisted of tree variables: origin country, product category and notifying country. The second cluster consisted of seven variables: product type, notification type, risk decision, notification basis, year, distribution status and action taken. However, within second cluster one can talk about two smaller clusters, i.e.: 
product type, notification type, risk decision and notification basis and year, distribution status and action taken. The following variables: product category and notifying country, product type and notification type, year and distribution status, were linked directly. It indicated that within the variables in question, the number of values was small and/or the same values of two variables in question often occurred together.

Figure 1. Tree diagram

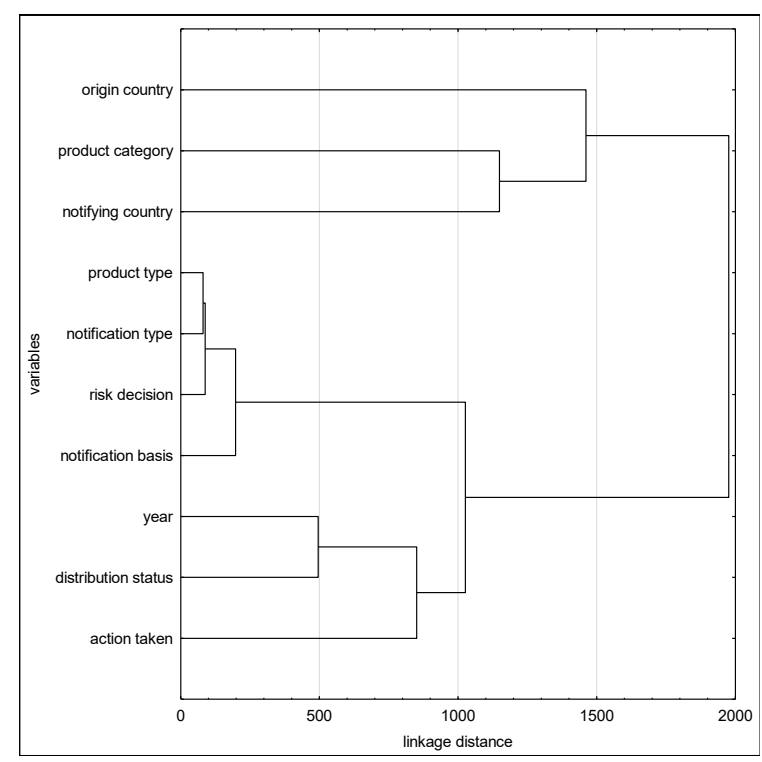

Source: own study.

In table 1 there are presented the results of k-means clustering with an indication of two, three, four or five clusters. The particular clusters were separated by semicolons.

Table 1 Results of k-means clustering

\begin{tabular}{|c|l|}
\hline $\begin{array}{c}\text { Clusters } \\
\text { number }\end{array}$ & \multicolumn{1}{c|}{ Variables } \\
\hline 2 & $\begin{array}{l}\text { origin country, product category, notifying country; product type, notification type, } \\
\text { risk decision, notification basis, year, distribution status, action taken }\end{array}$ \\
\hline 3 & $\begin{array}{l}\text { origin country, product category, notifying country; product type, notification type, } \\
\text { risk decision, notification basis; year, distribution status, action taken }\end{array}$ \\
\hline
\end{tabular}




\begin{tabular}{|c|l|}
\hline $\begin{array}{c}\text { Clusters } \\
\text { number }\end{array}$ & \multicolumn{1}{c|}{ Variables } \\
\hline 4 & $\begin{array}{l}\text { origin country; notifying country; product type, notification type, risk decision, } \\
\text { notification basis, distribution status; product category, year, action taken }\end{array}$ \\
\hline 5 & $\begin{array}{l}\text { origin country; product category; notifying country; product type, notification type, } \\
\text { risk decision, notification basis; year, distribution status, action taken }\end{array}$ \\
\hline
\end{tabular}

Source: own study.

The results of k-means clustering were the same as in tree clustering only in case of two clusters. When indicated three, four or five clusters, subsequent variables separated and formed a separate, single-element clusters. So, when indicated five clusters formed three one-element clusters (i.e.: origin country, product category and notifying country) and two other clusters consisting of the variables: product type, notification type, risk decision and notification basis and year, distribution status and action taken.

In the subsequent (bubble) scatterplots there is presented the dependence of the origin country and following variables: product category (fig. 2), product type (fig. 3), notification type (fig. 4), year (fig. 5), notification basis (fig. 7), notifying country (fig. 8), distribution status (fig. 9), action taken (fig. 10) and risk decision (fig. 11).

Figure 2. Dependence of the origin country and product category

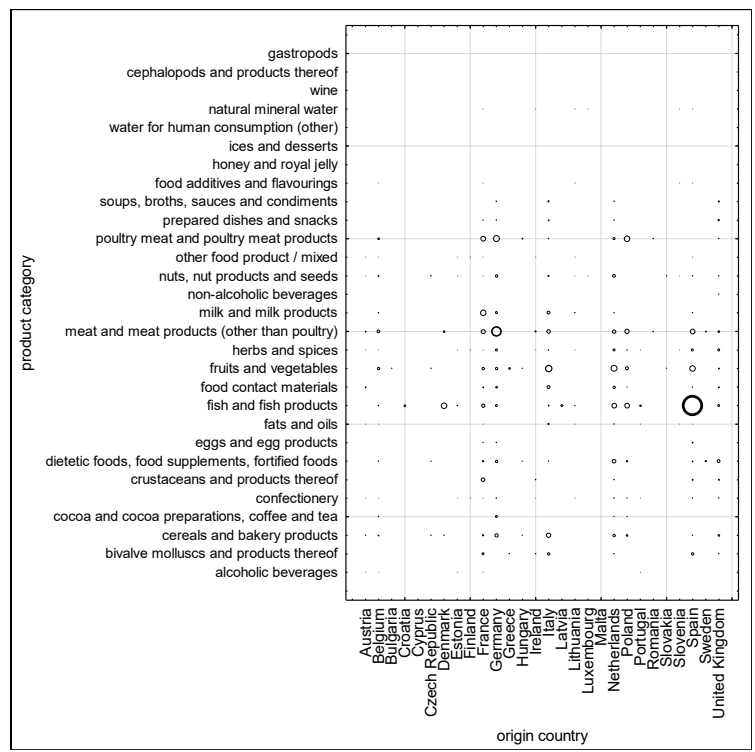


Figure 3. Dependence of the origin country and product type

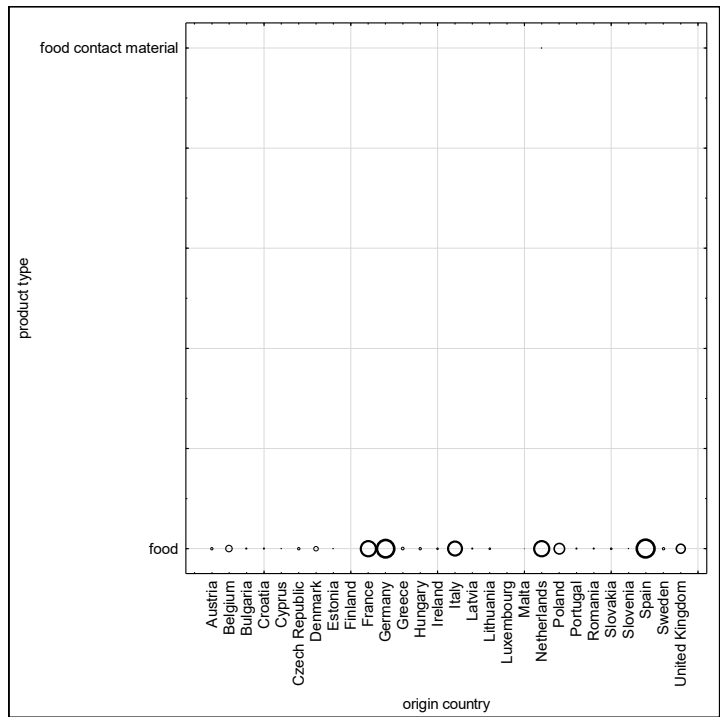

Source: own study.

Figure 4. Dependence of the origin country and notification type

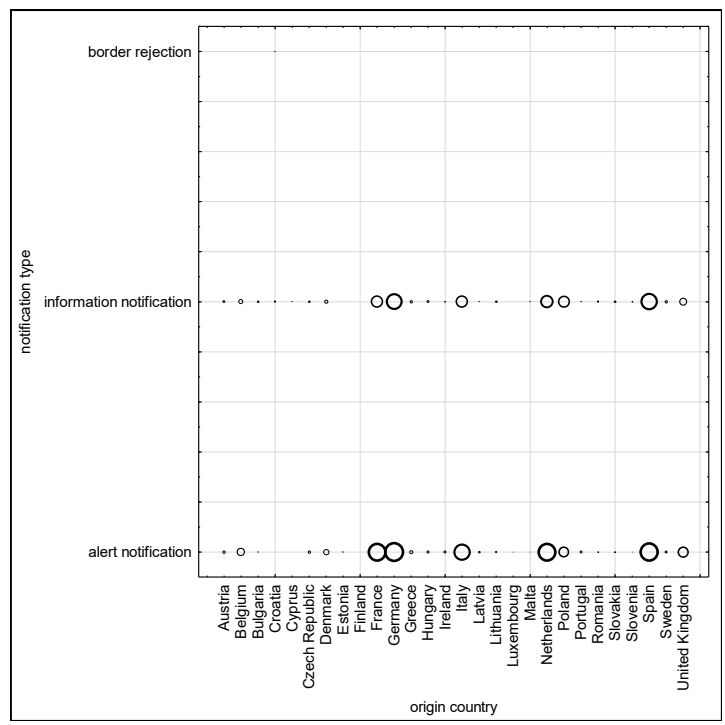

Source: own study. 
Figure 5. Dependence of the origin country and year

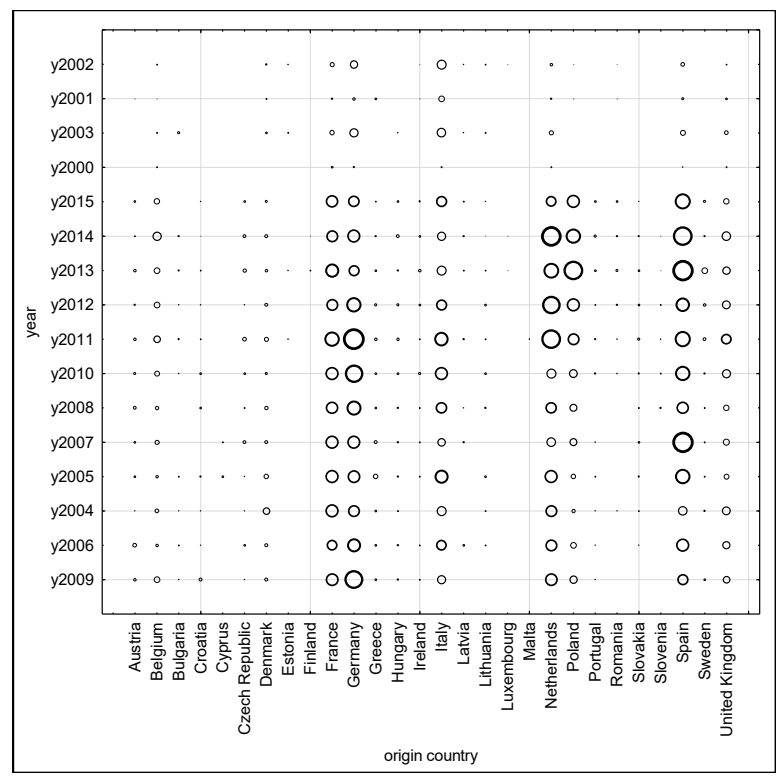

Source: own study.

Figure 6 . The number of notifications within notification types

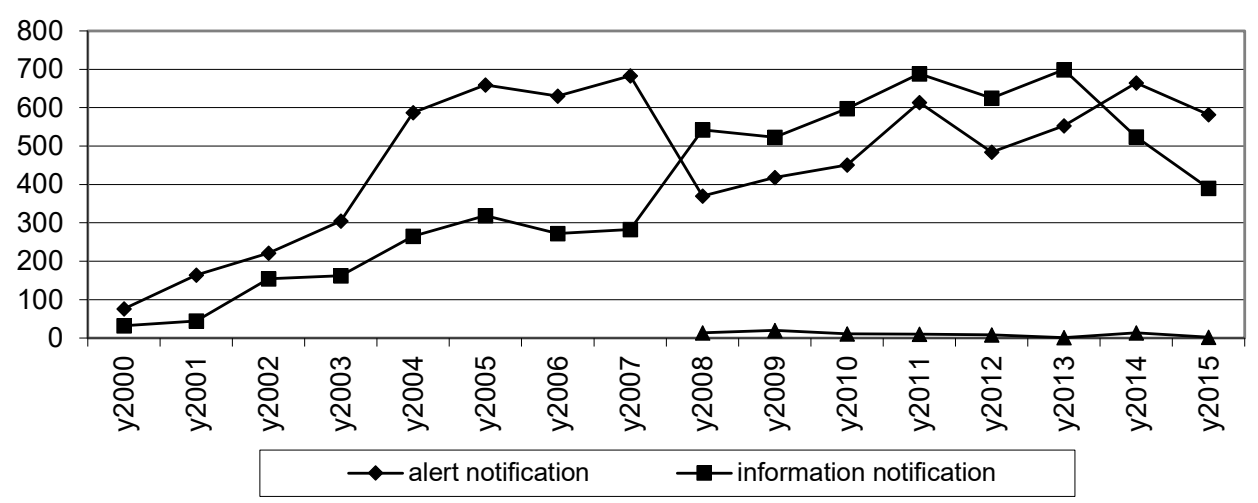

Source: own study. 
Figure 7. Dependence of the origin country and notification basis

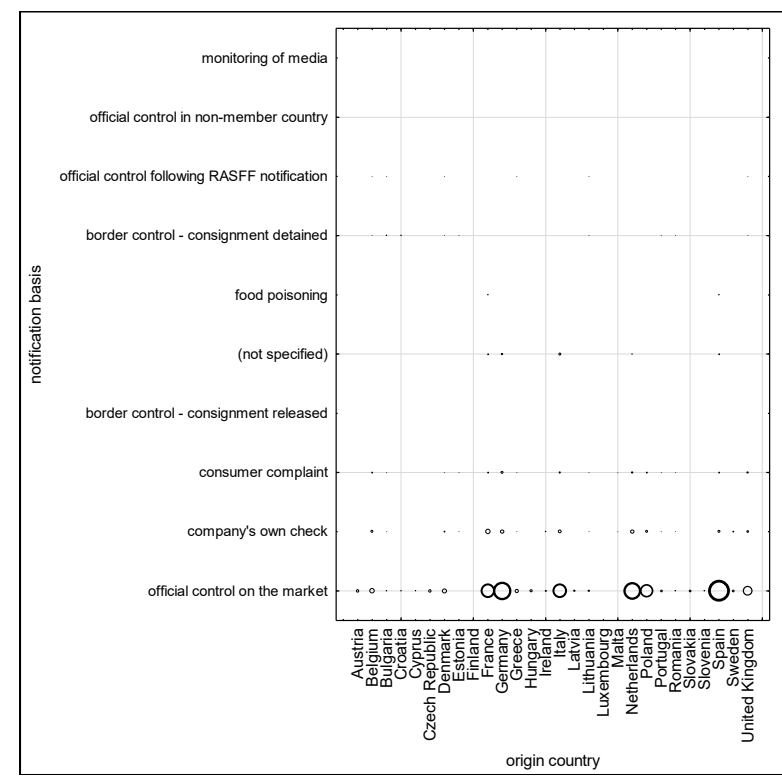

Source: own study.

Figure 8 . Dependence of the origin country and notifying country

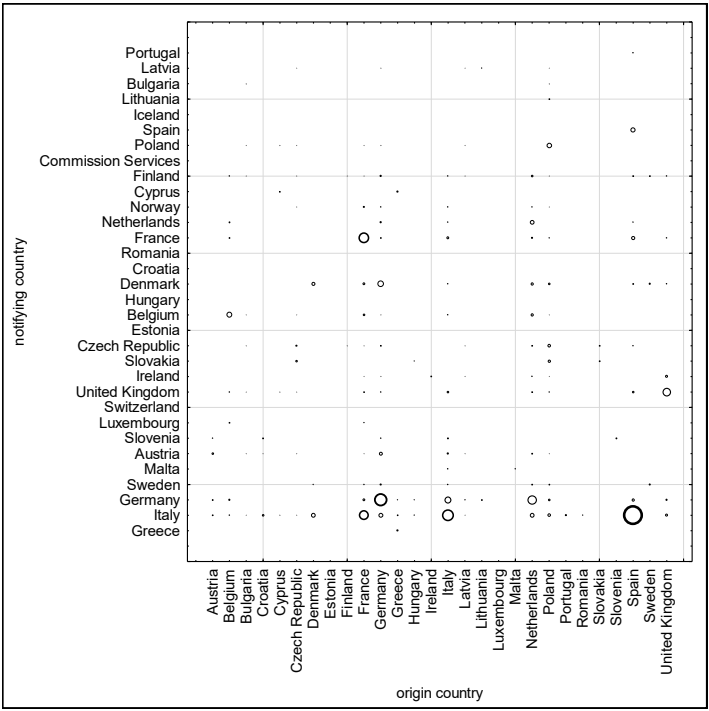

Source: own study. 
Figure 9. Dependence of the origin country and distribution status

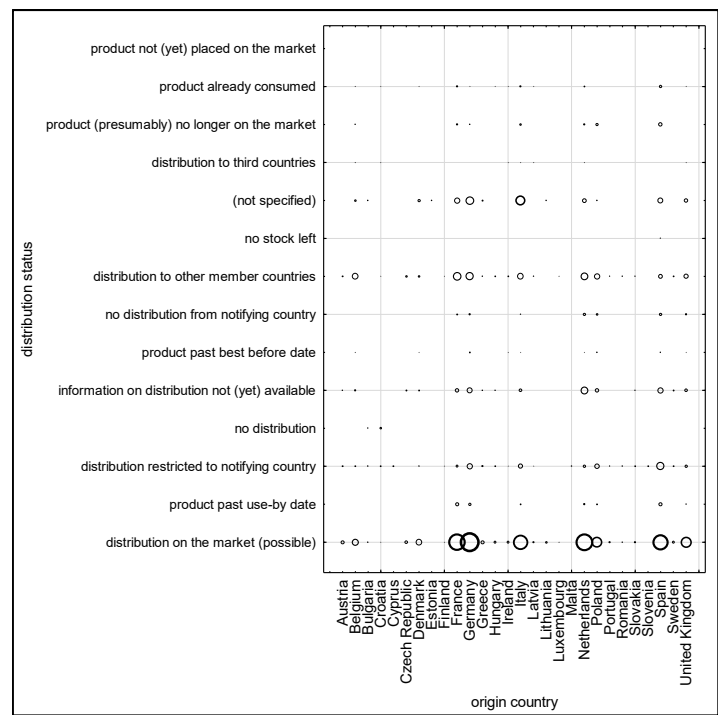

Source: own study.

Figure 10. Dependence of the origin country and action taken

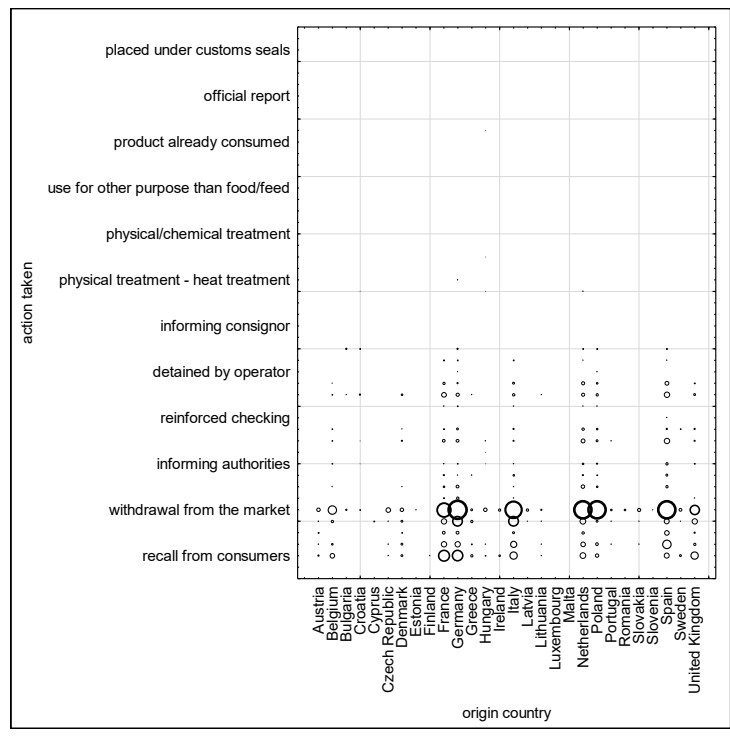

Source: own study. 
Figure 11. Dependence of the origin country and risk decision

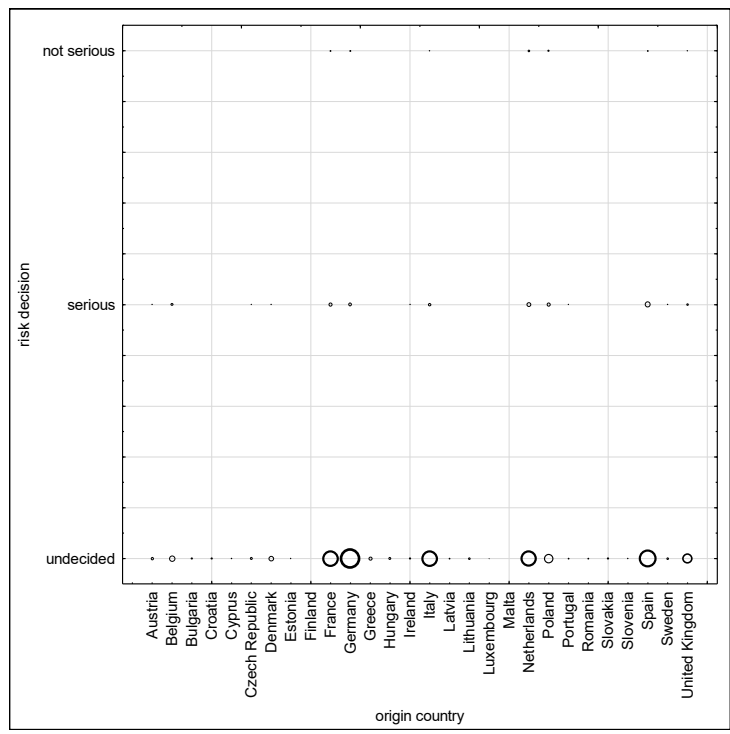

Source: own study.

Food that was the most frequently notified originated from: France, Germany, Italy, Netherlands, Spain and also from Poland and United Kingdom (fig. 2-5, 7-11). All these countries, except the Netherlands, are main EU economies. The vast majority of notifications related to food, not food contact materials (fig. 3). However, the particular attention should be paid to notifications on fish and fish products from Spain and, to a much lesser extent, to notifications on meat and meat products from Germany (fig. 2). Vázquez-Sánchez, López-Cabo, Saá-Ibusquiza, Rodríguez-Herrera (2012, p. 294) mentioned, for example, that about $25 \%$ of fishery products from retail sector in Spain (Galicia) in 2008 and 2009 were contaminated with Staphylococcus aureus. In turn, Wall and Kennedy (2011, pp. 66-67) indicated Germany as origin country with the largest number of alert notifications on meat and meat products in 2007-2009. The notified hazards were Salmonella typhimurium, Listeria monocytogenes, incomplete/incorrect certification and incorrect temperature control. Andrée, Jira, Schwind, Wagner, Schwägele (2010, p. 45) without pointing to the origin of meat, mentioned the RASFF notifications on presence of metabolites of nitrofurans. 
As shown in figure 4 and 6 , there were mainly alert notifications (7,462 notifications) and information notifications (6,120) (see European..., 2017a). An alert notification was sent when food presenting a serious risk is on the market and rapid action was or may be required. An information notification concerned food for which a risk was not serious or product was not on the market (European..., 2016, p. 7). There were only 80 border rejections and this notification type related primarily to Croatia (see European..., 2017a) before it accessed the EU. A very small number of border rejections pointed indirectly on the free movement of food within the common market (see also discussion related to fig. 5).

The arrangement of bubbles in figure 4 allows to assume that there was correlation between alert and information notifications. And so, the value of calculated Pearson's correlation coefficient was very high, namely 0.97 . The population size $n$ was 28 (number of countries), adopted significance level $\alpha$ was 0,05 , number of degrees of freedom $n-2$ was 26 , value of critical statistics $t_{\alpha ; n-2}$ was 2.06 and it was lower than the calculated statistics $|t|$, which was 21.54 . Thus, it can be stated that the number of notifications to food from the countries in question related to serious risk and risk which is not serious was similar.

The largest number of notifications, both alert and information notifications, was in 2011-2014. However, the number of notifications began to rise since 2004 (fig. 5 and 6), which could have two reasons. First, in 2004 official controls on the market was introduced (see European..., 2004) and second, in 2004 ten countries accessed the EU. The notification basis were just first of all the official controls on the market (fig. 7). As shown in figure 6, the number of alert notifications decreased significantly after introducing border rejections in 2008 (see European..., 2017a), which could mean that imported raw materials were used in the EU for food production (Pigłowski, 2017, p. 25) or food was repacked/re-exported. Hoffbauer, Remm, Lehmensiek (2012, p. 325) also indicated that introducing official controls on imports was effective (see also European..., 2009). The European Commission is currently working on the review of legislation on official controls (European..., 2017b).

As shown in figure 8, Italy notified food from Spain, Italy and France, Germany notified food from Germany and the Netherlands, France notified food from France, and the United Kingdom notified food from the United Kingdom. Italy, Germany, the United Kingdom and Spain were indicated by Petróczi, Taylor, Nepusz, Naught- 
on (2010, p. 1957) and Taylor, Petróczi, Nepusz, Naughton (2013, p. 413) as countries which notified food in the RASFF most frequently.

The status of the notifying products was most frequently defined as "distribution on the market (possible)" (fig. 9). Therefore, the action taken to notifying products was withdrawal from the market and recall from consumer (fig. 10). However, although the notifications were alert or information did not make a decision whether the risk was serious or not. The risk decision was defined as "undecided" (fig. 11), which was a kind of inconsistency, if it referred to the previously mentioned notification types.

\section{Conclusion}

After tree clustering, two clusters formed; first consisting of variables: origin country, product category and notifying country, and second containing variables: product type, notification type, risk decision, notification basis, year, distribution status and action taken. The results of k-means clustering were similar when indicating two clusters, however, the subsequent variables separated from first cluster when adopting more clusters.

The scatterplots allowed to indicate dependences between values of particular variables. The most frequently notified food (variable product type) originated from: France, Germany, Italy, the Netherlands, Spain and also from Poland and the United Kingdom (origin country). However, the particular attention should be paid to fish and fish products (product category) from Spain and to meat and meat products from Germany.

In the examined period in the RASFF notified mainly alert notifications and information notifications (notification type). The decrease of alert notifications since 2008 pointed out the effectiveness of border rejections resulting from border controls. The largest number of notifications, both alert and information notifications, was in 2011-2014 (year).

The notification basis was mainly the official controls on the market (notification basis). Food was notified mostly by: Italy, Germany, France and the United Kingdom (notifying country). The status of notifying food was most often "distribution on the market (possible)" (distribution status) and food was withdrawn from the 
market and recalled from consumer (action taken). However, the risk decision was defined as "undecided" (risk decision).

\section{References}

Andrée, S., Jira, W., Schwind, K.-H., Wagner, H., Schwägele, F. (2010). Chemical safety of meat and meat products. Meat Science, 86, 38-48. DOI:10.1016/j.meatsci.2010.04.020.

European Commission (2009). Commission Regulation (EC) No 669/2009 of 24 July 2009 implementing Regulation (EC) No 882/2004 of the European Parliament and of the Council as regards the increased level of official controls on imports of certain feed and food of non-animal origin and amending Decision 2006/504/EC (Text with EEA relevance). OJ L 194, 25.7.2009, pp. 11-21.

European Commission (2013). Keeping European Consumers Safe. 2012 Annual Report on the operation of the Rapid Alert System for non-food dangerous products. Luxembourg: Publications Office of the European Union.

European Commission (2016). RASFF - The Rapid Alert System for Food and Feed - 2015 annual report. Luxembourg: Publications Office of the European Union.

European Commission (2017a). RASFF - Food and Feed Safety Alerts. Retrieved from: https://ec.europa.eu/food/safety/rasff_en (27.01.2017).

European Commission (2017b). Review of legislation on official controls. Retrieved from: https://ec.europa.eu/food/safety/official_controls/review_en (27.02.2017).

European Parliament, Council (2002). Regulation (EC) No 178/2002 of the European Parliament and of the Council of 28 January 2002 laying down the general principles and requirements of food law, establishing the European Food Safety Authority and laying down procedures in matters of food safety. OJ L 31, 1.2.2002, pp. 1-24.

European Parliament, Council (2004). Regulation (EC) No 882/2004 of the European Parliament and of the Council of 29 April 2004 on official controls performed to ensure the verification of compliance with feed and food law, animal health and animal welfare rules. OJ L 165, 30.4.2004, pp. 1-141.

Hoffbauer, J., Remm, K., Lehmensiek, O. (2012). Das europäische Schnellwarnsystem RASFF: Erkenntnisse und Trends. Journal für Verbraucherschutz und Lebensmittelsicherheit, 7, 313-325. DOI 10.1007/s00003-012-0787-7.

Petróczi, A., Taylor, G., Nepusz, T., Naughton, D.P. (2010). Gate keepers of EU food safety: Four states lead on notification patterns and effectiveness. Food and Chemical Toxicology, 48, 1957-1964. DOI:10.1016/j.fct.2010.04.043. 
Pigłowski, M. (2017). Dangerous food from the Western and Eastern European Union countries in the Rapid Alert System for Food and Feed. Towaroznawcze Problemy Jakości. Polish Journal of Commodity Science, 51, 22-32. DOI: 10.19202/j.cs.2017.02.02.

Śmiechowska, M. (2013). Autentyczność i identyfikowalność w aspekcie zapewnienia jakości i bezpieczeństwa towarów. Gdynia: Akademia Morska w Gdyni.

Taylor, G., Petróczi, A., Nepusz, T., Naughton, D.P. (2013). The Procrustean bed of EU food safety notifications via the Rapid Alert System for Food and Feed: Does one size fit all? Food and Chemical Toxicology, 56, 411-418. DOI: 10.1016/j.fct.2013.02.055.

Vázquez-Sánchez, D., López-Cabo, M., Saá-Ibusquiza, P., Rodríguez-Herrera, J.J. (2012). Incidence and characterization of Staphylococcus aureus in fishery products marketed in Galicia (Northwest Spain). International Journal of Food Microbiology, 157, 286-296. DOI: 10.1016/j.ijfoodmicro.2012.05.021.

Wall, P., Kennedy, J. (2011). Food safety and processed meats: globalisation and the challenges. In: J.P. Kerry, J.F. Kerry (eds), Processed Meats. Improving Safety, Nutrition and Quality. Cambridge: Woodhead Publishing Limited.

\title{
POWIADOMIENIA WOBEC ŻYWNOŚCI Z KRAJÓW UNII EUROPEJSKIEJ W SYSTEMIE RASFF
}

\begin{abstract}
Abstrakt
W artykule opisano badanie na temat tego, z jakich krajów Unii Europejskiej była najczęściej zgłaszana żywność niebezpieczna w ramach Systemu Wczesnego Ostrzegania o Niebezpiecznej Żywności i Paszach (RASFF). Badaniu poddano 13662 zgłoszeń z lat 2000-2015. Zastosowano analizę skupień metodą aglomeracji oraz metodą k-średnich, a także wykresy rozrzutu. Do niezbędnych obliczeń wykorzystano program Excel i Statistica 12. Wskazano zależność pomiędzy krajem pochodzenia niebezpiecznej żywności i następującymi zmiennymi (i wartościami, które wystąpiły najczęściej): kategorią produktu (ryby z Hiszpanii, mięso z Niemiec), typem produktu (żywność), typem zgłoszenia (alarmowe i informacyjne), rokiem (2011-2014), podstawą zgłoszenia (urzędowe kontrole na rynku), krajem zgłaszającym (odpowiednio do kategorii produktów: Włochy, Niemcy), statusem dystrybucji (możliwa dystrybucja na rynku), podjętymi działaniami (wycofanie z rynku, wycofanie od konsumentów) i decyzją o ryzyku (brak wskazania).
\end{abstract}

Słowa kluczowe: niebezpieczna żywność, rynek europejski, System Wczesnego Ostrzegania o Niebezpiecznej Żywności i Paszach (RASFF) 